\title{
PENGENALAN MEDIA MASSA DAN PROFESI JURNALIS DI SMP KATOLIK ABDI SISWA JAKARTA BARAT
}

\author{
Roswita Oktavianti ${ }^{1}$
}

${ }^{1}$ Fakultas Ilmu Komunikasi, Universitas Tarumanagara, Jakarta

Email: roswitao@fikom.untar.ac.id

\begin{abstract}
Communication Study Programme is one of the programmes in tertiary education that generates human resources with journalist's competencies. A journalist who works in a press company or mass media has a role as a pillar of democracy and has a responsibility to distribute information to the public. However, this role is becoming increasingly challenging due to the rise of citizen journalism in online media and social media. Internet users can now spread information to their audiences. Therefore, the community services team of the Faculty of Communication, Universitas Tarumanagara held an event of introductory communication science, particularly in terms of a journalist as a media worker and mass media. This introduction of mass media and journalism is conducted with groups of junior high school students in Abdi Siswa Catholic Junior High School, West Jakarta, Indonesia. The team as communication academia initially conveyed about communication study and mass communication as one of the main areas. Then it expanded toward several of mass media in Indonesia, journalists or media workers, and the source of news of the journalists. Besides, the team also giving an understanding and insight about how students can contribute to delivering information toward media. This community service event aims to give the understanding of mass media and journalists as media workers, based on the perspective of practitioners and academia. The speaker was a journalist so the experienced and information relevant to the situation. The students were given a test afterwards, and it showed that students comprehend of mass media and journalist as a profession with an average score 7,37 out of 10. The introductory of journalism practice can be effective if the speaker enriches its presentation visually, using an interactive method, and it is delivered directly by the journalist or by the former journalist.
\end{abstract}

Keywords: community service, the introductory, mass media, journalist

\begin{abstract}
ABSTRAK
Program Studi Ilmu Komunikasi di perguruan tinggi menciptakan lulusan yang salah satunya memiliki kompetensi sebagai seorang jurnalis. Jurnalis atau wartawan yang bekerja pada perusahaan pers atau media massa berfungsi sebagai pilar demokrasi dan memiliki tanggung jawab sebagai penyalur informasi kepada masyarakat. Namun, tugas ini menjadi semakin menantang ketika jurnalis dihadapkan pada jurnalisme warga di media online dan media sosial yang juga mampu menyalurkan informasi kepada khalayak. Oleh karena itu, tim pengabdian kepada masyarakat Fakultas Ilmu Komunikasi Universitas Tarumanagara memberikan pengenalan tentang Ilmu Komunikasi secara umum, khususnya terkait profesi jurnalis dan media massa. Pengenalan dilakukan pada siswa Sekolah Menengah Pertama Katolik Abdi Siswa I dan II, Jakarta Barat. Tim pengabdian mengenalkan Ilmu Komunikasi, lalu komunikasi massa sebagai salah satu area utama dalam komunikasi, berbagai jenis media massa, profesi jurnalis, hingga sumber-sumber berita jurnalis. Selain itu, tim pengabdian juga memberikan pemahaman tentang kontribusi siswa sekolah dalam praktik jurnalisme. Tujuan dari kegiatan pengabdian kepada masyarakat ini adalah untuk memberikan pemahaman tentang media massa dan profesi jurnalis dari praktisi sekaligus akademisi yang pernah memiliki pengalaman sebagai jurnalis. Dari hasil tes berupa pertanyaan yang diberikan setelah kegiatan, menunjukkan bahwa siswa memahami materi tentang media massa dan profesi jurnalis dengan nilai rata-rata 7,37 dari nilai maksimal 10. Pengenalan dunia jurnalistik yang dilakukan dengan cara presentasi yang diperkaya dengan visual, interaktif, dan disampaikan oleh pembicara yang memiliki pengalaman langsung sebagai jurnalis lebih dapat diterima oleh para siswa.
\end{abstract}

Kata kunci: pengabdian masyarakat, pengenalan, media massa, jurnalis, wartawan

\section{PENDAHULUAN}

Jurnalistik merupakan salah satu kajian dalam Ilmu Komunikasi. Kegiatan jurnalistik merupakan kegiatan mencari, memperoleh, memiliki, menyimpan, mengolah, dan menyampaikan informasi baik dalam bentuk tulisan, suara, gambar, suara dan gambar, serta data dan grafik maupun dalam bentuk lainnya dengan menggunakan media cetak, media elektronik, dan segala jenis saluran yang tersedia. Kegiatan jurnalistik ini dilaksanakan secara teratur oleh jurnalis atau wartawan (Undang Undang RI Nomor 40 Tahun 1999 tentang Pers). 
Dalam Ilmu Komunikasi, bidang kajian jurnalistik ini berada pada konteks komunikasi massa. Komunikasi massa adalah komunikasi yang diperantarai oleh media massa yang yang ditujukan kepada audiens massa. Bentuk komunikasi massa antara lain buku, film, televisi, radio, surat kabar, majalah, website dan bentuk komunikasi visual (termasuk teknologi komputer) dan cetak lainnya yang mencapai massa (orang). Namun, komunikasi massa tidak termasuk one-on-one komunikasi elektronik seperti pesan email dan pesan instan (texting) (Wood, 2011).

Kenyataannya, masih ada individu, khususnya siswa sekolah menengah, yang belum bisa membedakan berita atau informasi di media massa dan informasi di media sosial dan pesan instan. Dari hasil survei pada kegiatan pengabdian masyarakat di SMA Kristoforus 1, Jakarta Barat, tentang berita palsu, masih ada siswa yang belum mampu mengenali berita atau informasi palsu. Siswa tersebut (walaupun jumlahnya hanya 11 persen dari total responden) belum mampu mengidentifikasi apakah informasi yang diterima berasal dari media massa tenar dan menggunakan penulisan berita yang terstruktur rapi (Oktavianti \& Loisa, 2017). Dalam hal ini, masih ada yang belum mampu mengidentifikasi media massa yang kredibel dan diakui di Indonesia.

Media pers berbeda dari media bukan-pers/non-pers. Format atau bentuk tampilan media bukan pers secara sepintas sulit dibedakan oleh kaum awam. Contohnya media partisan, atau media yang mendukung atau berasal dari lembaga penganut ideologi partai politik atau mewakili golongan masyarakat/mengembangkan paham tertentu. Publikasi dari media partisan ini tidak dapat dikategorikan sebagai media pers walaupun cara menyajikan informasi dan pendapatnya tidak jauh berbeda dengan gaya penulisan dan penyiaran media pers (Atmakusumah, 2020).

Dalam UU Pers tahun 1999, media massa merujuk pada pers nasional, yakni pers yang diselenggarakan oleh perusahaan pers Indonesia. Perusahaan pers adalah badan hukum Indonesia yang menyelenggarakan usaha pers meliputi perusahaan media cetak, media elektronik, dan kantor berita, serta perusahaan media lainnya yang secara khusus menyelenggarakan, menyiarkan, atau menyalurkan informasi. Hingga akhir tahun 2019, Dewan Pers mencatat sebanyak 511 media massa di Indonesia yang telah terverifikasi secara administrasi dan faktual. Dari jumlah tersebut, sebanyak 250 merupakan media massa cetak, 211 merupakan media massa berbasis internet atau siber, 45 merupakan media elektronik televisi, dan 5 merupakan media elektronik radio (Kaparino, 2020).

Komunikasi massa adalah sumber utama informasi dan hiburan (Wood, 2011). Penelitian yang dilakukan oleh tenaga ahli Dewan Pers, Winarto, pada akhir 2019 menunjukkan bahwa media siber atau portal berita menempati posisi tertinggi media massa yang diakses oleh responden (masyarakat). Selanjutnya, masyarakat memperoleh informasi dari pesan instan WhatsApp dan media sosial (Instagram, Facebook, Twitter), disusul televisi (termasuk TV streaming), dan surat kabar. Sementara media elektronik radio (termasuk radio streaming) jarang diakses oleh masyarakat. Penelitian Winarto dilakukan di 34 provinsi di Indonesia dengan responden dengan pendidikan sekolah menengah pertama hingga strata 2 (Winarto, 2020). Kendati demikian, diketahui bahwa pesan instan dan media sosial menjadi sumber masyarakat mengakses berita. Sementara berita yang tersebar melalui pesan instan WhatsApp dan jejaring sosial belum tentu bersumber pada media massa yang terverifikasi di Dewan Pers atau ditulis oleh jurnalis media massa.

Oleh karena itu, penting bagi masyarakat terutama siswa sekolah memahami terlebih dahulu apa saja media massa yang kredibel dan dapat diandalkan/dapat dipercaya. Lalu, hal penting berikutnya yang perlu diketahui sejak dini yakni terkait penulis dari berita tersebut. Apakah berita 
tersebut ditulis oleh penulis yang memang memiliki kompetensi untuk menginformasikan pesan tersebut kepada masyarakat? Dalam hal ini, siswa perlu dibekali pengetahuan dan wawasan tentang profesi jurnalis.

Fakultas Ilmu Komunikasi Universitas Tarumanagara pernah melakukan kegiatan pengabdian kepada masyarakat yakni anggota ekstrakurikuler penyiaran dan jurnalistik di SMA Kanaan, Jakarta Pusat pada Agustus 2020. Kegiatan yang berjudul "Mengenal Jurnalistik dan Mengenal Berita" dilakukan secara online di tengah kondisi pandemi Covid-19. Dari hasil survei yang dibagikan pada 33 peserta ekstrakurikuler, sebelum kegiatan dilaksanakan sebanyak $78,8 \%$ peserta tidak mengetahui definisi jurnalistik, walaupun peserta di dalamnya merupakan anggota ektrakurikuler penyiaran dan jurnalistik. Namun setelah dilakukan kegiatan pengabdian berupa pemberian materi dan diskusi, sebanyak $87,7 \%$ memahami definisi jurnalistik (Junaidi, Loisa \& Paramita, 2020). Hasil ini menunjukkan bahwa, kegiatan pengabdian dalam bentuk pemberian materi yang dilakukan secara daring mampu meningkatkan pemahaman tentang jurnalistik.

Oleh karena itu, kegiatan pengabdian kepada masyarakat terkait pengenalan profesi jurnalis dan media massa dilakukan kembali pada siswa-siswi secara daring. Kali ini kegiatan akan dilakukan pada siswa-siswi di SMP Katolik Abdi Siswa II berlokasi di Komplek Taman Aries Blok E9 No.1, Meruya Utara, Kecamatan Kembangan, Jakarta Barat. Kegiatan pengabdian masyarakat sebelumnya pernah dilakukan pada Desember 2018 di sekolah yang sama dengan judul "Pengenalan llmu Komunikasi: Public Speaking dan Literasi Media Sosial".

Dari latar belakang tersebut, tim pengabdi bersama mitra mengidentifikasi masalah yakni:

a. Siswa belum mengetahui definisi media massa dan mengidentifikasi media massa kredibel di Indonesia

b. Masyarakat mengakses informasi/berita dari media siber berupa media online, media sosial dan pesan instan. Sementara, berita yang tersebar melalui pesan instan WhatsApp dan jejaring sosial belum tentu bersumber pada media massa yang terverifikasi di Dewan Pers atau ditulis oleh jurnalis media massa.

c. Sebelum diberikan pemahaman berupa materi jurnalistik oleh dosen sekaligus praktisi (jurnalis), siswa yang memiliki ketertarikan pada penyiaran dan jurnalistik memiliki pemahaman yang masih rendah terkait jurnalistik.

d. Sekolah Abdi Siswa pernah menerima materi Pengenalan Ilmu Komunikasi: Public Speaking dan Literasi Media Sosial, namun belum mendapatkan materi terkait Jurnalisme yang diberikan oleh praktisi/pelaku media massa.

Solusi atas permasalahan tersebut yakni dengan mengadakan kegiatan pengabdian kepada masyarakat untuk meningkatkan pemahaman siswa dan guru tentang profesi jurnalis media massa. Selain itu, juga menambah pemahaman dan pengetahuan tim pengabdi sebagai akademisi Ilmu Komunikasi terkait pengetahuan dan pemahaman yang selama ini ada di kalangan para siswa terkait dunia jurnalistik khususnya profesi jurnalis.

\section{METODE PELAKSANAAN PKM}

Pada tahap persiapan, tim pengabdian kepada masyarakat menerima permintaan untuk mengisi kegiatan secara online di SMP Katolik Abdi Siswa II pada bulan Desember 2020. Kegiatan pengenalan dilakukan secara online karena kondisi pandemi Covid-19 menyebabkan semua sekolah melakukan pembelajaran jarak jauh. Lokasi SMP Katolik Abdi Siswa II sendiri terletak di Jalan Patra Tomang Raya, Jakarta Barat dan Komplek Taman Aries, Jakarta Barat. Setelah masalah dipetakan, dilakukan studi pustaka untuk pembuatan proposal. Tim pengabdian kepada masyarakat mempersiapkan kegiatan ini. 
Tahap pelaksanaan kegiatan dilakukan selama dua jam, dengan cara: pertama: tim pengabdian kepada masyarakat memperkenalkan ilmu komunikasi, lalu komunikasi massa; kedua, pemberian materi mulai fokus pada media massa, profesi jurnalis dan berita yang dibuat oleh jurnalis; ketiga, diskusi atau tanya jawab dengan para siswa; dan keempat adalah tes dalam bentuk soal pilihan ganda (multiple-choice) yang dilakukan secara online untuk mengetahui persentase pemahaman siswa terhadap materi yang telah diberikan (tentang media massa dan jurnalis). Guru pendamping yang juga hadir pada saat acara online tersebut juga diperkenankan mengisi tes tersebut.

Terakhir, tahap evaluasi. Efektivitas dari kegiatan pengenalan ini diketahui dari: pertama, hasil tes dalam bentuk pertanyaan pilihan ganda dengan sarana google form yang dikirimkan kepada seluruh peserta kegiatan setelah selesai acara mengetahui pemahaman siswa terhadap materi yang telah diberikan (tentang media massa dan jurnalis); kedua, tim pengabdian kepada masyarakat memaparkan hasil evaluasi tersebut pada para siswa dan guru; ketiga, dilakukan olah data, publikasi di media massa, penyusunan laporan akhir kegiatan, penyusunan artikel untuk dipublikasikan di jurnal/prosiding dan diseminasi pada seminar/konferensi.

\section{HASIL DAN PEMBAHASAN}

\section{Deskripsi Jalannya Kegiatan Pengabdian Masyarakat: Pengenalan Media Massa dan Profesi Jurnalis}

Kegiatan Pengabdian Kepada Masyarakat Fakultas Ilmu Komunikasi Universitas Tarumanagara dilaksanakan pukul 08.00 hingga pukul 10.00 WIB. Kegiatan dilaksanakan secara online melalui sarana konferensi video Zoom. Berdasarkan pemantauan Zoom Meeting, jumlah peserta dalam pertemuan ini sebanyak 140 peserta. Kegiatan dibuka oleh Kepala Sekolah SMP Katolik Abdi Siswa II yang disampaikan oleh Kepala Sekolah Drs. Antonius Mardiyono, MM. Selanjutnya, Tim Pengabdian Kepada Masyarakat Fakultas Ilmu Komunikasi Universitas Tarumanagara Roswita Oktavianti, S.Sos., M.Si., memperkenalkan diri dan menjelaskan garis besar kegiatan. Kegiatan PKM ini dapat dilihat pada Gambar 1 dan Gambar 2.

Tim pengabdi memberikan materi secara langsung. Materi diawali dengan pengenalan Ilmu Komunikasi dan area utama komunikasi yaitu komunikasi intrapribadi, komunikasi antarpribadi, komunikasi tim dan kelompok, komunikasi publik, komunikasi organisasi, komunikasi massa, media pribadi dan media sosial (komunikasi digital), dan komunikasi antarbudaya. Media massa masuk dalam kajian komunikasi massa. Media massa adalah sarana untuk menyampaikan informasi kepada sejumlah orang yang jumlahnya relatif besar dan tersebar. Industri yang masuk dalam kategori industri media massa yaitu stasiun televisi, stasiun radio, media cetak (surat kabar dan majalah), buku, video games, dan media online. Para siswa ditanya terkait media online yang pernah diakses.

Berikutnya, penjelasan beralih tentang profesi jurnalis, dimulai dari definisi jurnalis atau wartawan, kegiatan jurnalistik, dan undang-undang/regulasi yang mengatur kerja jurnalistik. Tim pengabdi menunjukkan sejumlah jurnalis terkenal di Indonesia yang sebagian besar merupakan jurnalis/pembawa berita (anchor) di televisi. Ini untuk menunjukkan pada peserta bahwa jurnalis lain (media cetak dan media online), kerap tidak dikenal karena tidak tampil di layar kaca dan cenderung bekerja di balik layar. Tim pengabdi turut memberikan pengalaman suka-duka menjadi jurnalis untuk memberikan gambaran kepada peserta mengenai profesi jurnalis.

Setelah membahas mengenai profesi jurnalis, tim pengabdi menjelaskan tentang berita atau news yang biasanya dibuat oleh para jurnalis. Berita merupakan laporan tentang fakta, atau peristiwa atau pendapat, yang dipublikasikan secara luas melalui media massa. Berita ini diperoleh dari 
berbagai kegiatan atau peristiwa. Pada bagian ini, tim pengabdi menjabarkan apa saja yang bisa diberitakan atau menjadi bahan pembuatan berita oleh jurnalis. Contohnya: hasil wawancara dengan narasumber, persidangan, pawai, upacara, diskusi, hingga yang banyak dilakukan oleh jurnalis saat ini yaitu unggahan di media sosial.

\section{Gambar 1}

Kegiatan Pengabdian kepada Masyarakat "Pengenalan Media Massa dan Profesi Jurnalis" secara Daring di SMP Katolik Abdi Siswa Jakarta Barat

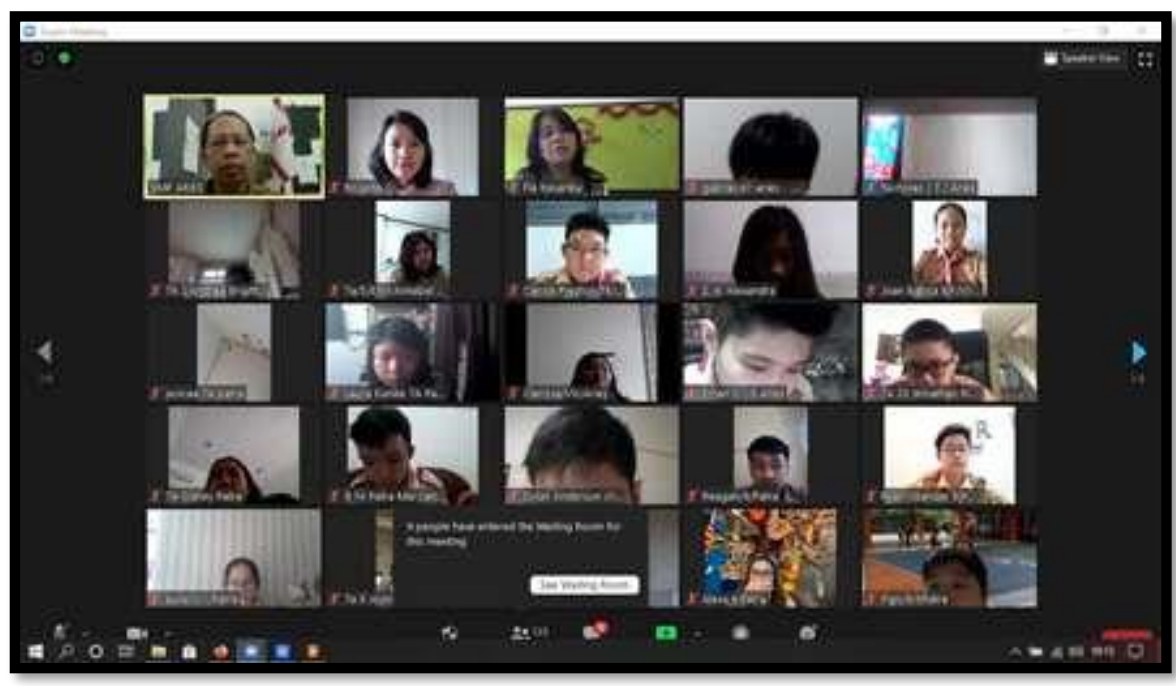

\section{Gambar 2}

Kepala Sekolah SMP Katolik Abdi Siswa II Jakarta Barat, Antonius Mardiyono Membuka Kegiatan Online "Pengenalan Media Massa dan Profesi Jurnalis"

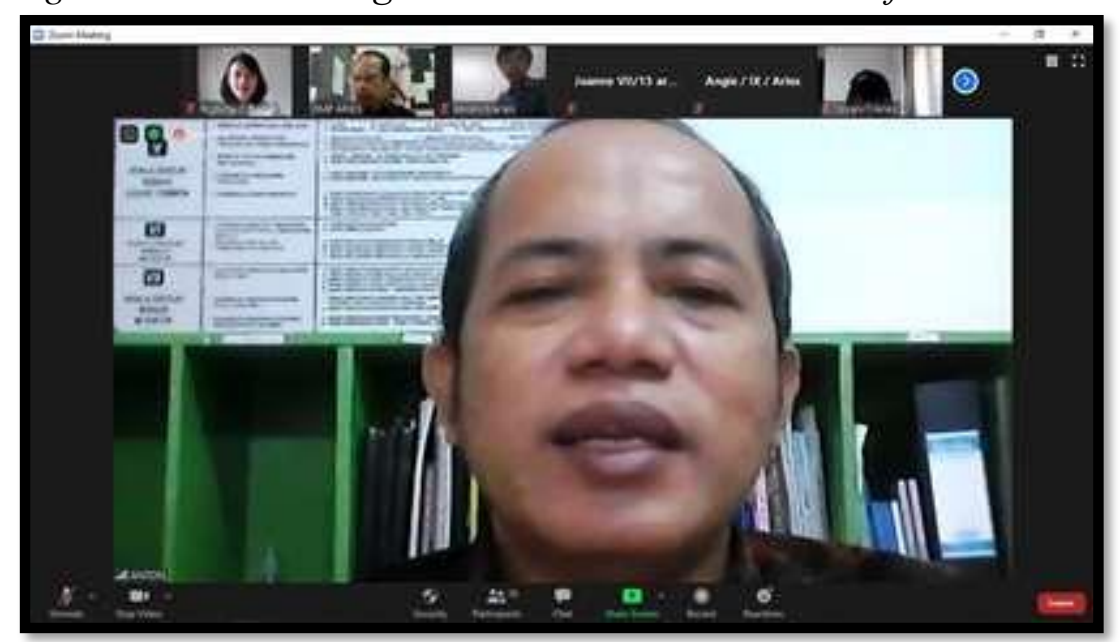

Dalam sesi tanya jawab, terdapat beberapa pertanyaan dari siswa. Salah satunya yaitu "apakah untuk menjadi jurnalis atau menyampaikan informasi/berita kita harus menjadi wartawan terlebih dahulu?" Pertanyaan ini dijawab pada saat presentasi, khususnya pada pembahasan tentang jurnalisme warga (citizen journalism). Jurnalisme warga sendiri berarti warga yang melaporkan langsung. Contohnya warga melaporkan melalui media sosial, blog, opini, atau kolom di media massa. Para siswa, meskipun belum lulus perguruan tinggi, bisa berkontribusi memberikan informasi yang akurat serta menyampaikan pendapat melalui blog pribadi, blog/kanal yang disediakan untuk pembaca oleh media online, hingga opini di media massa cetak. 


\section{Hasil Kegiatan Pengabdian Masyarakat: Pengenalan Media Massa dan Profesi Jurnalis}

Di akhir acara, tim pengabdi meminta seluruh peserta untuk mengisi soal pilihan ganda dengan memindai QR Code di layar presentasi. Pertanyaan ini berupa tes pengetahuan dan wawasan yang sudah diperoleh dari kegiatan pengabdian kepada masyarakat yang berlangsung selama dua jam. Pertanyaan yang diajukan dan persentase jawaban yang benar dapat dilihat pada Tabel 1.

\section{Tabel 1}

Soal Pilihan Ganda untuk Mengukur Efektivitas Kegiatan Pengabdian Kepada Masyarakat

\begin{tabular}{|c|c|c|c|}
\hline No & Pertanyaan & Pilihan Jawaban & $\begin{array}{c}\text { Persentase } \\
\text { Jawaban Benar }\end{array}$ \\
\hline 1. & $\begin{array}{l}\text { Andri mengeluh longgarnya penerapan protokol } \\
\text { kesehatan di sebuah supermarket. Petugas tidak } \\
\text { mengecek suhu badan pengunjung yang datang. Ia } \\
\text { menyampaikan kritiknya di kanal "Opini" salah satu } \\
\text { media online di Indonesia. Bentuk komunikasi } \\
\text { apakah yang dilakukan Andri? }\end{array}$ & $\begin{array}{l}\text { a. Komunikasi Kelompok } \\
\text { b. Komunikasi } \\
\text { Antarpribadi } \\
\text { c. Komunikasi Organisasi } \\
\text { d. Komunikasi Massa }\end{array}$ & $61,3 \%$ \\
\hline 2. & $\begin{array}{l}\text { Pilihlah di bawah ini mana yang bukan bentuk media } \\
\text { massa. }\end{array}$ & $\begin{array}{l}\text { a. Surat kabar } \\
\text { b. Surat } \\
\text { c. Radio } \\
\text { d. Televisi }\end{array}$ & $80,6 \%$ \\
\hline 3. & $\begin{array}{l}\text { Pilihlah di bawah ini mana yang merupakan media } \\
\text { massa. }\end{array}$ & $\begin{array}{l}\text { a. Akun YouTube Atta } \\
\text { Halilintar } \\
\text { b. Zoom SMP Abdi Siswa } \\
\text { c. Stasiun Televisi RCTI } \\
\text { d. Surat dari kepala } \\
\text { sekolah }\end{array}$ & $82,3 \%$ \\
\hline 4 & $\begin{array}{l}\text { Pilihlah di bawah ini mana yang merupakan } \\
\text { jurnalis/wartawan resmi media massa. }\end{array}$ & $\begin{array}{l}\text { a. Beauty Vlogger Tasya } \\
\text { Varasya } \\
\text { b. Wartawan Majalah Tempo } \\
\text { Rosihan Anwar } \\
\text { c. Influencer @ Catwomanizer } \\
\text { d. Pegiat Podcast Deddy } \\
\text { Corbuzier }\end{array}$ & $87,1 \%$ \\
\hline 5. & $\begin{array}{l}\text { Yang manakah di bawah ini hal yang paling tepat } \\
\text { dalam mendeskripsikan kerja seorang } \\
\text { wartawan/jurnalis? }\end{array}$ & $\begin{array}{l}\text { a. Jejaring luas (banyak } \\
\text { teman/relasi) } \\
\text { b. Waktu dan durasi kerja } \\
\text { pasti } \\
\text { c. Bertemu dengan orang yang } \\
\text { sama setiap hari } \\
\text { d. Tugas liputan mudah } \\
\text { diprediksi }\end{array}$ & $67,7 \%$ \\
\hline 6. & $\begin{array}{l}\text { Yang manakah di bawah ini hal yang paling tepat } \\
\text { dalam menunjukkan dampak kerja } \\
\text { wartawan/jurnalis? }\end{array}$ & $\begin{array}{l}\text { a. Mampu memberi perubahan } \\
\text { positif pada seseorang, } \\
\text { institusi, atau negara } \\
\text { b. Menunjukkan potret } \\
\text { kehidupan masyarakat } \\
\text { Indonesia } \\
\text { c. Memberi informasi lebih } \\
\text { akurat daripada media } \\
\text { sosial } \\
\text { d. Jawaban semua benar }\end{array}$ & $54,8 \%$ \\
\hline 7. & $\begin{array}{l}\text { Berikut ini yang bukan merupakan sumber berita } \\
\text { jurnalis/wartawan }\end{array}$ & $\begin{array}{l}\text { a. Pameran produk mebel } \\
\text { buatan pengusaha muda } \\
\text { Indonesia }\end{array}$ & $64,5 \%$ \\
\hline
\end{tabular}


8. Jika Anda seorang jurnalis yang ingin mengetahui perkembangan vaksin Covid-19 di Indonesia, siapa yang akan Anda wawancara?

9. Saat ini Anda masih sekolah di SMP Katolik Abdi Siswa Jakarta Barat, bagaimana caranya Anda bisa menulis secara komprehensif mengenai vaksin dari kacamata siswa namun tulisan Anda masih bisa dilihat banyak orang?

10. Saat ini Anda masih sekolah di SMP Katolik Abdi Siswa Jakarta Barat, bagaimana caranya Anda bisa menulis mengenai vaksin dari kacamata siswa namun tulisan Anda bisa dipublikasikan di media massa? (berbeda dengan pertanyaan no.9)
b. Unggahan pernyataan
Presiden Joko Widodo di akun Instagram @jokowi
c. Penangkapan pengedar narkoba
d. Blog pribadi
a. Perawat di Puskesmas terdekat
$93,5 \%$
b. Dokter di RS swasta termahal
c. Guru sekolah
d. Menteri Kesehatan
a. Melamar menjadi jurnalis di $\quad 75,8 \%$ perusahaan media massa
b. Menulis di buku harian
c. Menulis di buku catatan sekolah
d. Membuat blog dan menuangkan ide Anda dalam blog tersebut (blogspot, wordpress, dll)
a. Menulis di buku harian
b. Menulis di blog media Detik, Okezone dll
c. Menulis di media sosial pribadi
d. Melamar menjadi jurnalis/wartawan online seperti Kompasiana,

Tabel 1 menunjukkan 10 (sepuluh) pertanyaan dan pilihan jawaban yang semuanya sudah dijelaskan dalam presentasi tim pengabdi. Pertanyaan dan pilihan jawaban yang diberikan juga menuntut kejelian para siswa.

Sebanyak 62 jawaban diterima oleh tim pengabdi. Nilai rata-rata untuk seluruh jawaban adalah 7,37 dari nilai maksimal 10. Sepuluh soal yang diujikan dalam tes pilihan berganda mewakili semua materi yang sudah diberikan. Pertanyaan 1 terkait dengan komunikasi massa di dalamnya ada media massa, sebagai area utama dari komunikasi. Pertanyaan 2 dan 3 menguji kemampuan siswa dalam membedakan industri media massa dan bukan media massa. Pertanyaan 4 menguji kemampuan siswa dalam membedakan profesi jurnalis dan bukan jurnalis. Pertanyaan 5 dan 6 menguji kemampuan siswa dalam mengidentifikasi kerja jurnalis dan dampak kerja jurnalis. Dari sisi pemberitaan, pertanyaan 7 dan 8 merepresentasikan kemampuan siswa dalam mengetahui sumber dan narasumber yang tepat untuk berita yang dibuat oleh jurnalis. Terakhir, pertanyaan 9 dan 10 menunjukkan sisi keterlibatan dalam pemberitaan di mana siswa mengetahui perannya sebagai jurnalisme warga.

\section{Diskusi/Pembahasan Hasil Kegiatan Pengabdian Masyarakat: Pengenalan Media Massa dan Profesi Jurnalis}

Di tengah terpaan informasi di media sosial, semakin sulit membedakan berita atau informasi yang diperoleh dari media massa resmi yang dibuat oleh jurnalis/wartawan, dengan informasi yang dibuat oleh pengguna atau user generated content. Menurut Undang Undang RI Nomor 40 Tahun 1999 tentang Pers, wartawan adalah orang yang secara teratur melaksanakan kegiatan jurnalistik. Wartawan bekerja pada perusahaan pers, sebuah badan hukum Indonesia yang menyelenggarakan 
usaha pers seperti media cetak, elektronik, kantor berita, dan perusahaan yang secara khusus menyelenggarakan, menyiarkan, dan menyalurkan informasi.

Sementara itu, artikel Verklin \& Kenner berjudul "Why Newspapers Hate Craig and His Infamous 'List"' menunjukkan bahwa penyaji informasi tidak lagi pada industri-industri yang menguasai media, tetapi semua orang. Perubahan besar ini disebabkan oleh digitalisasi dan perubahan dari media lama ke media baru. Jika media lama melakukan framing melalui konten. Dalam dunia digital, semua orang menjadi pengguna (user) dan juga pembuat. Media massa dan pelaku media (wartawan) lama-kelamaan hanya menjadi fasilitator (Kanner \& Verklin, 2007).

Semakin buramnya batas berita dan informasi yang dibuat oleh jurnalis media massa resmi (pers di Indonesia) dengan informasi yang dibuat oleh pengguna media menjadi keprihatinan guru di sekolah. Siswa usia sekolah tidak bisa membedakan mana berita yang dibuat oleh media massa resmi (perusahaan pers) dan media yang dibuat oleh pengguna (tidak terdaftar di Dewan Pers). Sekolah dan guru di sekolah perlu menyikapi persoalan ini dengan mengadakan pengenalan media massa, profesi jurnalis dan berita yang dibuat jurnalis. Hal ini agar, para siswa mampu membedakan mana berita yang berasal dari media resmi berbadan hukum yang diakui oleh pemerintah Indonesia, dan mana berita yang memang dibuat untuk tujuan komersil bukan oleh lembaga pers.

Selain itu, profesi jurnalis sendiri perlu kembali diingatkan kepada para siswa. Saat ini, influencer di media sosial (YouTuber, Selebgram, Selebtweet, TikTok dll) serta informasi yang dibagikan di media sosial semakin banyak, membuat siswa atau pengguna media sosial usia muda dengan mudah terpengaruh. Padahal, informasi yang dibagikan belum tentu bisa dipertanggungjawabkan. Tidak ada pengawas di dalam aliran informasi di media sosial. Berbeda dengan berita di media massa yang sudah melalui tahap penyuntingan oleh apa yang disebut Shoemaker dengan penjaga gerbang editorial (editorial gatekeeping). Penjaga gerbang media (media gatekeeping) merupakan proses di mana seseorang mengontrol aliran pesan melalui saluran komunikasi (contoh penjaga gerbang media adalah editor surat kabar dan direktur berita televisi) (Dearing \& Rogers, 1996).

Tim pengabdian kepada masyarakat Fakultas Ilmu Komunikasi Universitas Tarumanagara dan SMP Katolik Abdi Siswa Jakarta Barat, menyelenggarakan kegiatan di bidang jurnalistik. Secara bertahap, para siswa diperkenalkan tentang ilmu komunikasi, komunikasi massa sebagai salah satu area komuniksi, mengenali media massa, profesi jurnalis, berita yang dibuat oleh jurnalis, serta bagaimana siswa sebagai kaum muda berkontribusi pada aliran informasi di ranah digital.

Dari hasil tes soal pilihan ganda, kegiatan yang berlangsung secara online ini efektif membentuk pemahaman tentang dunia jurnalistik kepada para siswa. Para siswa sebagian besar mampu menjawab pertanyaan yang diajukan segera setelah kegiatan selesai.

Dari hasil tes dan evaluasi dengan mitra, kegiatan pengabdian kepada masyarakat berupa pengenalan media massa dan profesi jurnalis ini bisa berjalan baik. Sebagian besar peserta memahami materi yang diberikan. Sejumlah aspek yang mempengaruhi efektivitas pemberian materi adalah:

a. Presentasi diberikan dengan menyertakan sejumlah foto dan gambar (daripada sekedar tulisan), agar para siswa yang tengah menjalani pembelajaran jarak jauh tidak bosan/jenuh. Para siswa juga tidak hanya berimajinasi ketika diberikan penjelasan tentang jurnalis, sumber berita jurnalis, dan peran siswa sebagai pembuat konten. Dalam hal ini, tim pengabdi menyertakan sejumlah foto dan gambar industri media massa, jurnalis, sumber-sumber berita, dan menunjukkan kanal/sarana membuat dan menyebarkan konten di media massa. 
b. Presentasi diberikan langsung oleh pelaku media massa atau jurnalis atau orang yang pernah berkecimpung dalam pers nasional. Dalam hal ini, tim pengabdi sebelumnya pernah menjadi jurnalis media massa sehingga yang disampaikan berdasarkan pengalaman nyata didukung dengan bukti-bukti berupa foto. Materi yang disampaikan menjadi lebih bisa diterima audiens.

c. Presentasi diberikan secara interaktif dalam bentuk tanya-jawab, atau berlangsung dua arah. Kondisi pembelajaran jarak jauh merupakan tantangan para pengajar/pemberi materi. Oleh karena itu, pemberi materi perlu melibatkan beberapa peserta dalam pembelajaran online tersebut.

Kegiatan pengabdian kepada masyarakat ini juga dipublikasikan lewat media online beritasatu.com seperti yang dapat dilihat pada Gambar 3 .

\section{Gambar 3}

Publikasi Kegiatan Pengabdian kepada Masyarakat "Pengenalan Media Massa dan Profesi Jurnalis" di Media Online Beritasatu.com (Prasetyo, 2021)

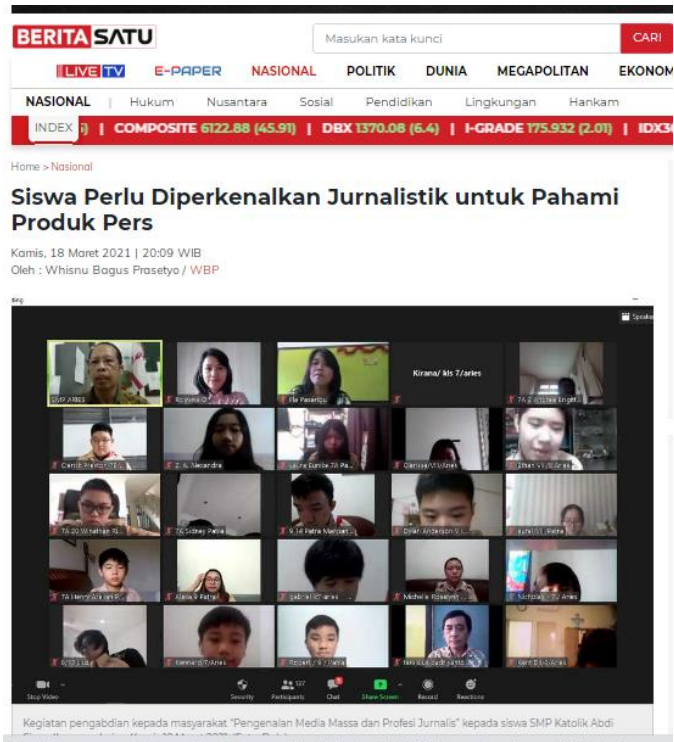

\section{KESIMPULAN DAN SARAN}

Kegiatan pengabdian kepada masyarakat berupa pengenalan media massa dan profesi jurnalis yang diadakan secara daring ini ditujukan memberi pemahaman tentang media massa dan profesi jurnalis kepada para siswa. Di akhir kegiatan para siswa diberikan tes dalam bentuk pilihan ganda dengan soal yang mewakili semua materi yang sudah diberikan. Rata-rata nilai yang diperoleh yaitu 7,37 dari nilai maksimal 10 .

Dari hasil evaluasi bersama mitra, kegiatan pengabdian kepada masyarakat berupa pengenalan dunia jurnalistik yang dilakukan dengan cara presentasi online ini mudah dipahami oleh para siswa karena diperkaya dengan visual sehingga siswa yang berada dalam kondisi pembelajaran jarak jauh tidak merasa jenuh, bersifat interaktif atau komunikasi berlangsung dua arah, dan disampaikan oleh pembicara yang memiliki pengalaman langsung sebagai jurnalis sehingga lebih dapat diterima oleh para siswa.

Kegiatan ini dilaksanakan secara daring pada siswa SMP. Berikutnya, kegiatan memperkenalkan media massa dan profesi jurnalis bisa dilakukan pada anak-anak dengan usia lebih dini seperti siswa sekolah dasar. Semakin banyak informasi yang beredar di internet dan media sosial membuat pengguna menerima informasi tanpa menelaah sumber dan penulis informasi tersebut, apakah 
berasal dari media yang kompeten dan diakui sebagai pers nasional. Anak-anak rentan menerima informasi yang salah dan palsu jika tidak dibekali dengan pemahaman tentang media massa dan profesi jurnalis. Saat ini, media massa semakin sulit dibedakan dengan saluran lain yang dibuat pengguna. Begitupula posisi jurnalis semakin sulit dibedakan dengan pengguna internet (netizen). Oleh karena itu, pengenalan media massa dan jurnalis yang diakui Dewan Pers perlu dilakukan sedini mungkin, untuk menciptakan generasi masyarakat informasi yang cerdas dan mampu bijak dalam menyaring informasi.

\section{Ucapan Terima Kasih (Acknowledgement)}

Terima kasih kepada Lembaga Penelitian dan Pengabdian Masyarakat Universitas Tarumanagara atas dukungannya terhadap kegiatan ini, kepada mitra kegiatan pengabdian masyarakat, SMP Katolik Abdi Siswa Jakarta Barat, kepala sekolah, guru-guru pendamping, dan para siswa.

\section{REFERENSI}

Atmakusumah. (2020, Juni). Pers Partisan, Bolehkah? Dewan Pers. https://dewanpers.or.id/assets/ebook/jurnal/2009010545_2020-

08_JURNAL_21_Pers_dan_Dinamika_Politik_Indonesia.pdf

Dearing, J. W., \& Rogers, E. M. (1996). Communication Concepts 6. Sage Publication.

Junaidi, A., Loisa, R., \& Paramita, S. (November 2020). Edukasi Pengenalan Jurnalistik Kepada Generasi Digital. Jurnal Bakti Masyarakat Indonesia, 3(2), 506-513. https://journal.untar.ac.id/index.php/baktimas/article/view/9602/6655

Kanner, B., \& Verklin, D. (2007). Watch This, Listen Up, Click Here: Inside the 300 Billion Dollar Business Behind the Media You Constantly Consume. John Wiey \& Sons.

Kaparino, Y. (2020, Januari 09). Home: Politik. https://politik.rmol.id: https://politik.rmol.id/read/2020/01/09/416814/dewan-pers-sudah-511-media-massayang-terverifikasi-faktual

Oktavianti, R., \& Loisa, R. (2017). Penggunaan Media Sosial Sesuai Nilai Luhur Budaya di Kalangan Siswa SMA. Jurnal Pengabdian Kepada Masyarakat, 3(1), 86-95. doi:10.22146/jpkm.26925

Prasetyo, W. (2021, Maret 18). Siswa perlu diperkenalkan jurnalistik untuk pahami produk pers.

Berita Satu. https://www.beritasatu.com/nasional/747705/siswa-perlu-diperkenalkanjurnalistik-untuk-pahami-produk-pers

Undang Undang RI Nomor 40 Tahun 1999 tentang Pers. (t.thn.).

Winarto. (2020, Juni). Kepercayaan Publik Terhadap Pers Perlu Dikaji. Dewan Pers. https://dewanpers.or.id/assets/ebook/jurnal/2009010545_2020-

08_JURNAL_21_Pers_dan_Dinamika_Politik_Indonesia.pdf

Wood, J. T. (2011). Communication Mosaics an Introduction to the Field of Communication Sixth Edition. Wadsworth Cengage Learning. 